PÄÄKIRJOITUS

\title{
Pieni ja avoin tiedejulkaisija niin puhurina kuin purjeessa
}

\author{
Susanna Nykyri \\ Tampereen yliopiston kirjasto \\ susanna.nykyri@tuni.fi \\ https://orcid.org/0000-0002-5018-5176
}

Asiasanat: tieteellinen julkaisutoiminta, Helsinki-aloite, monikielisyys, avoin tieto, open access, vastuullisuus, rahoitus

Tiedejulkaisemisen kentällä tapahtuu paljon tahtotilan ilmaisemisessa. Selkeä tahtotila on kaikessa abstraktiudessaan juurikin sitä kivijalkaa, jota vasten käytäntöjä peilataan ja kehitetään.

Yksi vaikuttavista tahtotilan tarkennuksista ja ilmauksista on tieteellisen viestinnän monikielisyyden Helsinki-aloite. Aloitteelle ja tavoitteen toteutumiseksi kaivataan sitoutumista niin päätöksentekijöiltä, yliopistoilta, Artikkeli on lisensoitu Creative Commons Nimeä-EiKaupallinen-JaaSamoin 4.o Kansainvälinen -lisenssillä Pysyvä osoite: https://doi.org/10.23978/inf. 83329 
ammattikorkeakouluilta, tutkimuslaitoksilta, tutkimusrahoittajilta, kirjastoilta ja tutkijoilta. Suositukset on jaoteltu kolmen pääotsikon alle:

1. Tue tutkimustulosten levittämistä, jotta yhteiskunta hyötyy niistä täysipainoisesti.

2. Huolehdi kansallisista infrastruktuureista, jotka mahdollistavat paikallisesti tärkeän tutkimuksen julkaisemisen.

3. Edistä kielten moninaisuutta tutkimuksen arvioinnissa, arvostamisessa ja rahoittamisessa. (Avoin Tiede 2019; Helsinki Initiative on Multilingualism in Scholarly Communication 2019)

Taustalla on huomio siitä, että monikielisyyden tarve on kansainvälisesti jaettu kokemus, ja että monikielisyyden toteuttaminen on haastavaa rahoituksen ja tutkimusarvioinnin nykyisessä ilmapiirissä. Helsinki-aloitteen takana ovat Tieteellisten seurain valtuuskunta (TSV), Tiedonjulkistamisen neuvottelukunta (TJNK), Suomen tiedekustantajien liitto, Universities Norway (UHR) ja COST-toimi "European Network for Research Evaluation in the Social Sciences and the Humanities" (ENRESSH). (Emt.)

Helsinki-aloite on tällä hetkellä luettavissa peräti 28 kielellä. Aloite ansaitsee laajaa huomiota. Onkin hienoa, että mm. Suomen yliopistojen rehtorineuvosto UNIFI ry on allekirjoittanut aloitteen. Luonnollisestikin myös Informaatiotutkimus-lehti (ja samalla edustamansa ITY ry) on allekirjoittanut aloitteen.

Suomessa tiedejulkaiseminen on jo varsin kansainvälistä, ja englannin kielen merkitys monilla tieteenaloilla suuri.

"Suomalaisten yliopistojen tutkijat julkaisivat vuosina 2016-2017 tieteellisiä, ammatillisia ja yleistajuisia artikkeleita ja kirjoja yli 30 eri kielellä. Meisimpiä julkaisukieliämme ovat englanti ja suomi. Kaikista yliopistojen tuottamista julkaisuista englanninkielisten osuus on $70 \%$, suomenkielisten $26 \%$, ruotsinkielisten $2 \%$ ja muiden julkaisukielten osuus on $2 \%$. Vaikka englannista on tullut tieteen kansainvälinen valtakieli, tiedettä priorisoidaan, rahoitetaan, hallinnoidaan, tehdään, viestitään, tulkitaan, sovelletaan ja opetetaan tietyissä yhteiskunnallisissa ja kulttuurisissa konteksteissa, joissa puhutaan ja kirjoitetaan useita eri kieliä. Mikään kieli ei yksin riitä tieteen kieleksi." (Pölönen, Muhonen, Mustajoki 2019)

Eri tieteenalojen väliset painotuserot julkaisukielissä ja myös julkaisutyypeittäin ovat ymmärrettäviä ja tarpeenkin, mutta ihan kaikilla aloilla tarvitaan 
silti siis myös monikielisyyttä ja -muotoisuutta - ihan jo yhteiskunnallisen vaikuttavuuden toteuttamiseksi. Myös DORA ja Leidenin tutkimusmetriikkamanifesti nostavat esille tutkimustuotosten monimuotoisuuden ja paikallisuudenkin merkityksen. (Emt.)

Lehtemme on jo aiemmin sitoutunut DORA-julistukseen ja myös ilmaissut, että julkaisemme kirjoituksia niin suomeksi, ruotsiksi kuin englanniksi. Julkaisupäätös ei perustu julkaisukieleen, vaan kaikki tarjotut käsikirjoitukset ovat tältä osin samanarvoisia. Lehdellämme on hyvin varaa kasvattaa muun kuin suomenkielisten osuutta ja samalla vaalia monikielisyyden arvoa ja toteutumista. Konstit ovat monet! Lehdessämme mm. huolehditaan alan keskeisen monikielisen terminologian kehittämisestä mm. asiasanoin ja Yleisen suomalaisen ontogian (YSO) ${ }^{1}$ käyttöön ja myös sen kehittämiseen rohkaisten. Lisäksi me arvostamme julkaisemisen monimuotoisuutta toivomalla ja arvostamalla aktiivisesti eri julkaisutyyppejä edustavia käsikirjoituksia.

Vaan niin paljon kuin teemmekin, niin aina olisi varaa parantaa - myös monikielisyydessä. Englanninkielisten vertaisarvioitujen artikkelikäsikirjoitusten (A1/A2) osalta on edukseen todettava, että englanninkielisyys kasvattaa merkittävästi potentiaalisten vertaisarvioijien joukkoa - ja ilokseni lehden on ollut käytännössä heitä helppo myös rekrytoida. Niin tällaista rekrytointiprosessin sujuvuutta ja päätoimittajan työtä helpottamaan kuin lehden näkyvyyttä ja vaikuttavuutta kasvattamaan olisi kuitenkin omiaan, jos lehti saisi myös englanninkieliset sivut luotua. Tässä kuitenkin törmätään toisenlaiseen käytännön haasteeseen eli ns. vapaaehtoistyönä tehtävän työn vaatimaan aikaan, jota ei lehden aktiiveilla voi olla määräänsä enempää. Moni käytännön kehittämistyö jääkin siksi odottamaan ns. aikaa parempaa, mikä on usein myös turhauttavaa. Se, että oppiaineellamme on tutkimusta ja opetusta myös ruotsinkielisessä yliopistossamme Åbo Akademissa ja että sieltä on toimituskunnassamme aktiivinen edustus (Kristina Eriksson-Backa), on taannut sen, että ruotsin kielen osalta tätä puolta on onnistuttu jo kiitettävästi kehittämään.

Vapaaseen pääsyyn tietoon ja myös yhteiskunnalliseen vaikuttavuuteen kuuluu elimellisesti myös vastuullisesti ja laadukkaasti toteutettu avoin julkaiseminen. Lehden toiminnassa DOAJ-kriteerien täyttäminen on erinomainen lähtökohta osoittamaan, että lehti toimii selkeästi määriteltyjen vastuullista avointa julkaisemista koskevien kriteerien mukaisesti, mutta se ei vielä yksin riitä.

Tutkimusrahoittajien laatiman Plan S:n (cOAlition S 2019) uusi versio on jo luettavissa, ja keskeisiltä osin Informaatiotutkimus-lehti on sen kanssa jo nyt yhteensopiva. On kuitenkin joitain yksityiskohtia, joissa se haastaa

1 Ks. Informaatiotutkimus-lehden kirjoittajaohjeet (https://journal.fi/inf/about/submissions) ja Yleinen suomalainen ontologia (YSO) (http://finto.fi/yso/fi/). 
käytäntöjämme. Näitäkin haasteita ja tulevia kehittämiskohteita pohditaan toimituskunnassa - mutta voimavarojen ja rahantulon sekä -menon rajoissa. Kotimaisten tiedelehtien teknisen tuen osalta merkittävimmässä roolissa on TSV:n tarjoaman journal.fi-alustan käytön tuen kehittäminen - resursointikysymys sekin, vaikkakaan ei yksittäisen lehden vastuulla. Jotkin Plan S:n yksityiskohtaisemmat vaatimukset ovat lehden näkökulmasta yksinkertaisia toteuttaa, mutta valintana vaikeita - esimerkiksi haluammeko kertoa hyväksyttyjen ja hylättyjen käsikirjoitusten suhdeluvun. Toki ko. luku osaltaan lisää toimituksellisten päätösten läpinäkyvyyttä, mutta muuttuuko se uudenlaiseksi vaikuttavuuskertoimeksi ja onko se omiaan ohjaamaan väärällä tavalla julkaisupäätöksiä ja mielikuvia lehden laadusta.

Rahoituksen suhteen mietin, että pelastaisiko meidät ja laajemminkin tieteenteon ja sen tukemisen talouspinteestä uusi hallitusohjelma. Pessimisti ei pety, mutta optimisti on onnellinen. Nojaudunkin mielelläni TSV:n kehittämispäällikkö Henriikka Mustajoen (2019) arvioon, että meillä on syytä luottavaisuuteen.

Suomen avoimen tieteen kentällä kotimaisen tiedejulkaisemisen perustuminen pitkälti vapaaehtoistyöhön on kestämätön epäkohta, jonka soisi jo ratkeavan. Ratkaisu ja ratkaisemattomuus peilaavat tahtotilaa siitä, että onko meillä myös kotimaista laadukasta tiedejulkaisemista ja tehdäänkö sitä myös kansallisilla kielillä. Miten ja milloin meillä Suomessa siirrytään tukemaan tiedelehtien siirtymistä ja jo siirtyneiden toimintamahdollisuuksia välittömästi avoimina, laadukkaina ja vastuullisina tiedejulkaisuina, on akuutti kohtalonkysymys kotimaisille tiedelehdillemme.

Taloushaasteista huolimatta ainakaan Informaatiotutkimus-lehti ei olisi pärjännyt käsikirjoitusten houkuttelemisessa eikä julkaisemiensa kirjoitusten vaikuttavuuden mahdollistamisessa ilman välitöntä avoimuutta. Pienen tieteenalan kotimaiselle lehdelle avoimuus ja kehittävä toimitusote on ollut ja on elinehto.

Osa kehittävää toimintaa on lehden aktiivien kouluttautuminen ja osaamisen kehittäminen sekä verkostoituminen, joka ei onnistu yksinomaan muiden asiantuntijatehtävien lomassa eikä omatoimisesti. Lehtemme toimitussihteeri Harri Ollikainen osallistuikin Suomen tiedekustantajien liiton järjestämälle viimeisimmälle Tiedejulkaisemisen perusteet-kurssille, jolta allekirjoittaneella on myös erinomainen kokemus parin vuoden takaa. Ollikaiselta (2019) on tässä numerossa mielenkiintoinen kuvaus kurssin annista ja myös riittävää vastausta vailla olevia kysymyksiä ja haasteita:

"Ehkä mielenkiintoisinta ja hedelmällisintä antia kurssilla oli todeta konkreettisemmin se, miten valtava määrä työtä toimituksissa teh- 
dään. Ja sen ymmärtäminen, että niukkojen resurssien maailmassa käytäntöjen ja prosessien on syytä olla kunnossa. - - Kuka tämän kaiken työn sitten tekee ja millä resursseilla, on monille tiedelehdille tuttu kysymys, koska tieteellisten seurojen lehtiä tehdään pääsääntöisesti vapaaehtoisvoimin. Tehdään tätä työtä sitten meritoitumisen vuoksi tai silkasta intohimosta omaa alaa kohtaan, on hyvä pyrkiä tekemään tiedelehdissä tehtävä työ näkyvämmäksi. Vaikka ei haluttaisi niellä "enemmän vähemmällä" -retoriikkaa, on myös syytä huolehtia toiminnan optimoinnista ja tehtävien priorisoinnista. Suomessa lehtien välillä varsinaista kilpailua on vain nimeksi, minkä vuoksi yhteistyö tieteellisten seurojen kesken voisi olla yksi keino vastata edellä mainittuihin haasteisiin." (Emt.)

Tästä kirjoituksesta on hyvä edetä lukemaan samaisen numeron muuta antia, aiheinaan julkaiseminen ajattelun ja kirjoittamisen jatkumona; avoin data, avoin julkaiseminen ja kirjastot datayhteiskunnan solmuina - QQML 2019 konferenssin kuulumisia; ja verkossa tapahtuvan terveystietokäyttäytymisen ja ajan suhteesta.

Lehden monipuolisesta sisällöstä on jälleen kiittäminen kirjoittajia, kirjoituksia arvioineita, toimituskuntaa ja heistä erityisesti taas suuren työn tehnyttä Harri Ollikaista aktiivisesta ja innostavasta työotteestaan! Tämänkin lehden ilmestymisestä on kiittäminen myös jokaista ITY ry:njäsen-ja kannatusmaksun maksanutta!

Lopuksi haluan nostaa esille lokakuussa koittavat Tiedejulkaisemisen päivät, joiden teemana on tänä vuonna avoimuus, vastuullisuus ja kieli. Voit vaikuttaa päivien ohjelmaan lähettämällä ehdotuksesi puheenvuoroksi 31.8 . mennessä (ks. https://www.tsv.fi/fi/uutiset/tiedejulkaisemisen-p\%C3\%A4iv \%C3\%A4t-8\%E2\%80\%939102019).

Nötössä 27.6.2019 (17 m/s) Susanna Nykyri

\section{Lähteet}

Avoin Tiede (3.4.2019.) Uutiset. Helsinki-aloite - monikielisyys tutkimuksen ytimessä. URL: https://avointiede.fi/fi/uutiset/helsinki-aloite

cOAlition S (31.5.2019). Accelerating the transition to full and immediate Open Access to scientific publications. https://wWw.coalition-s.org/wp-content/uploads/PlanS_Principles_and_Implementation_310519.pdf

Helsinki Initiative on Multilingualism in Scholarly Communication (2019). Helsinki: Fede- 
ration of Finnish Learned Societies, Committee for Public Information, Finnish Association for Scholarly Publishing, Universities Norway \& European Network for Research Evaluation in the Social Sciences and the Humanities. https://doi.org/10.6084/m9. figshare. 7887059

Mustajoki, H. (6.6.2019). Hallitusohjelma tukee tutkitun tiedon avointa saatavuutta. Avoin tiede, uutiset. https://avointiede.fi/fi/uutiset/hallitusohjelma

Ollikainen, H. (2019). Suunnistusta tiedejulkaisemisen maastossa: Suomen tiedekustantajien liiton Tiedejulkaisemisen perusteet -kurssi 2018-2019. Informaatiotutkimus, 38(2). https://doi.org/10.23978/inf.83400

Osallistava ja osaava Suomi: hallitusohjelma (3.6.2019). Valtioneuvoston viestintäosasto, tiedote. https://valtioneuvosto.fi/artikkeli/-/asset_publisher/10616/sallistava-ja-osaava-suomi-sosiaalisesti-taloudellisesti-ja-ekologisesti-kestava-yhteiskunta

Pölönen, J., Muhonen, R. \& Mustajoki, H. (2019). Helsinki-aloite monikielisen tieteellisen viestinnän puolesta. Acatiimi 4/2019. http://www. acatiimi.fi/4_2019/20.php 